Article

\title{
Energy and Exergy Evaluations of a Combined Heat and Power System with a High Back-Pressure Turbine under Full Operating Conditions
}

\author{
Shifei Zhao ${ }^{1, * \mathbb{D}}$, Weishu Wang ${ }^{1}$ and Zhihua Ge ${ }^{2}$ \\ 1 School of Electric Power, North China University of Water Resources and Electric Power, Zhengzhou 450045, \\ China; wangweishu@ncwu.edu.cn \\ 2 National Thermal Power Engineering and Technology Research Centre, North China Electric \\ Power University, Beijing 102206, China; gezh@ncepu.edu.cn \\ * Correspondence: zhaoshifei@ncwu.edu.cn; Tel.: +86-152-1064-7031
}

Received: 27 July 2020; Accepted: 27 August 2020; Published: 31 August 2020

\begin{abstract}
High back-pressure technology is a promising method for the waste heat recovery of exhaust steams in combined heat and power systems. In this research, a $300 \mathrm{MW}$ coal-fired subcritical combined heat and power system was selected as the reference system, and modeled in EBSILON professional. Then, energy-based and exergy-based performances of the high back-pressure system and traditional combined heat and power system were compared under full operating conditions. Moreover, a novel exergy-based evaluation method, which considers the energy level of the heating supply, was proposed and applied to evaluate the two systems. Results show that: In design conditions, both the heating capacity and power output of the high back-pressure system were higher than those of the extraction condensing system, which led to $17.67 \%$ and $33.21 \%$ increments of the gross thermal efficiency and generation efficiency, respectively. Compared with the extraction condensing system, the exergy efficiencies of the high back-pressure system were 7.04-8.21\% higher. According to the novel exergy-based evaluation, the exergy efficiencies for the generation of the high back-pressure system and extraction condensing system were $46.48 \%$ and $41.22 \%$, respectively. This paper provides references for the thermodynamic performance evaluation of the combined heat and power system.
\end{abstract}

Keywords: combined heat and power; high back-pressure; thermodynamic performance; exergy-based efficiencies; full operating conditions

\section{Introduction}

Combined heat and power (CHP) is a well-proven energy-saving technology for fossil energies [1]. By the end of 2016, the gross installed capacity of CHP reached $755.2 \mathrm{GW}$ and kept incrementing by $2.8 \%$ per year [2]. In China, CHP is widely used in the coal-fired power plants due to the coal-dominated resource structure [3]. The total installed capacity was $435 \mathrm{GW}$ in 2018 , accounting for $39.4 \%$ of the coal-fired power plants. Hence, the technological innovation of CHP technology is essential for the energy industries around the world.

In the traditional CHP system, the steam for heating is usually extracted between the medium-pressure turbine and low-pressure turbine. In the meantime, the heat loss of exhaust steam is large and hard to recover due to its low energy level. Thus, the waste heat recovery of the CHP plant has been widely focused on and considered as a significant part in future district heating (DH) system. Currently, the CHP system with a high back-pressure turbine (CHP-HBP) has drawn more and more attention [4]. In the HBP system, with the improvement of the back-pressure of the low-pressure turbine, the temperature of the exhaust steam is largely increased. Then the exhaust steam can heat the thermal network water, which leads to nearly zero heat loss of the turbine [5]. Due to 
these characteristics, the HBP system has been widely applied to the CHP plant with capacities of $200 \mathrm{MW}, 300 \mathrm{MW}$ and $600 \mathrm{MW}$ in China [6]. Yang et al. presented a thermodynamic discussion about the cooperation of the HBP system and the low-temperature DH system, indicating that the lower temperature of the supplied-water would give a higher seasonal energy efficiency of the integrated system [7]. Li et al. compared the waste heat recovery technology of the exhaust steam and pointed out that the HBP system had the highest energy efficiency theoretically with the equivalent coefficient of 8.7 [8]. Li et al. developed the HBP system through the integration of the heat pump to ease the inflexibility of adjustment [9], and discussed the CHP system with multiple turbines, whose heating energy consumption is $47.7 \%$ lower than the conventional CHP system [10]. From the comprehensive utilization of the exhaust steam and flue gas, Zhao et al. proposed a novel system to optimize the joint operation of the HBP system and the traditional CHP system, which led to $5.06 \%$ increment of the generation efficiency [11]. Ma et al. proposed a novel cascading heating system composing by four turbine units, and the gross efficiency of the novel system could reach $85.7 \%$ [12]. Chen et al. also indicates the waste heat of the HBP system can be recovered in the coal pre-drying process, which would increase the generation efficiency by $1.7 \%$ [13]. Thus, CHP-HBP technology can enhance the heating capacity, and improve the energy efficiency of the CHP plant, which also has excellent compatibility with the low-temperature grid in 4th generation DH technology [14].

The evaluation method which guides the development of the CHP system, is also an essential part of the CHP research. Efficiencies and indicators for the CHP plant are typically based on the first law and second law of thermodynamics, which are also defined as energy-based and exergy-based methods [15]. Wang et al. performed a techno-economic analysis of the CHP system, which is the extension of the energy-based evaluation with the consideration of the feasibility and economic performance [16]. Yannay et al. studied the performance of the CHP system through the integration of thermodynamics with economic criteria [17]. From the aspect of the environmental emissions, Pouria et al. provided a thermo-environmental modeling for the CHP system, in which environmental emissions of $\mathrm{CO}, \mathrm{CO}_{2}$ and $\mathrm{NO}_{x}$ were considered [18]. Emin et al. applied the advanced exergy analysis to the trigenration system to reveal the potential for improvement of the components in the system [19]. Duccio et al. analyzed a micro CHP system fueled by solar and geothermal by thermo-economic analysis which combined exergy analysis and economic principles [20]. Besides, the "green heating $(\mathrm{GH})$ " theory proposed by Yang et al. is also supplementary to the existing evaluation system [21], in which the theoretical minimum specific fuel consumption is introduced and taken as the basic of GH index.

The traditional exergy-based evaluation method usually concerns the resources and products and their energy levels, but not the process. That means that the result is firmly based on the temperatures of the environment and different cold-ends. On the other hand, it also ignores the energy level difference between different types of CHP systems. It makes the exergy-based analysis of the CHP system complex, especially in the comparison of different CHP technologies. Thus, the innovation of $\mathrm{CHP}$ technology also calls for the development of the evaluation method.

Hence, this paper provides a novel exergy-based evaluation method, in which the heating process of the CHP system is well concerned. Due to the remove of the exergy consumption for heating from the total exergy input, this method can be used in not only the comparison among CHP systems with different heating sources, but also among the CHP systems and systems that only generate power.

In this research, a comprehensive thermodynamic analysis of the HBP system was conducted in both design and off-design conditions. By comparing it with the traditional CHP system, limitations of the conventional evaluation methods are discussed. Then, a novel exergy-based evaluation method is proposed, and it was applied to compare the different CHP systems. 


\section{System Description}

\subsection{Traditional CHP System}

In traditional coal-fired CHP plant, the live steam, which is generated directly from the boiler, is usually expanded in the high-pressure turbine (HPT) and medium-pressure turbine (MPT) first. Then, part of the steam will be extracted to heat the water through the thermal network heater (THN), while the rest is sent to the low-pressure turbine (LPT). This mode is also called the "extraction condensing (EC) system." By the cascade utilization of the steam and the decrease of the exhaust steam loss, the CHP system shows great advantages in energy conservation over the system that generates electricity only (power-only system). In this research, a $300 \mathrm{MW}$ coal-fired subcritical single-reheat power plant was selected as the reference system, which has three high-pressure regenerative heaters, three low-pressure regenerative heaters and one deaerator, as shown in Figure 1.

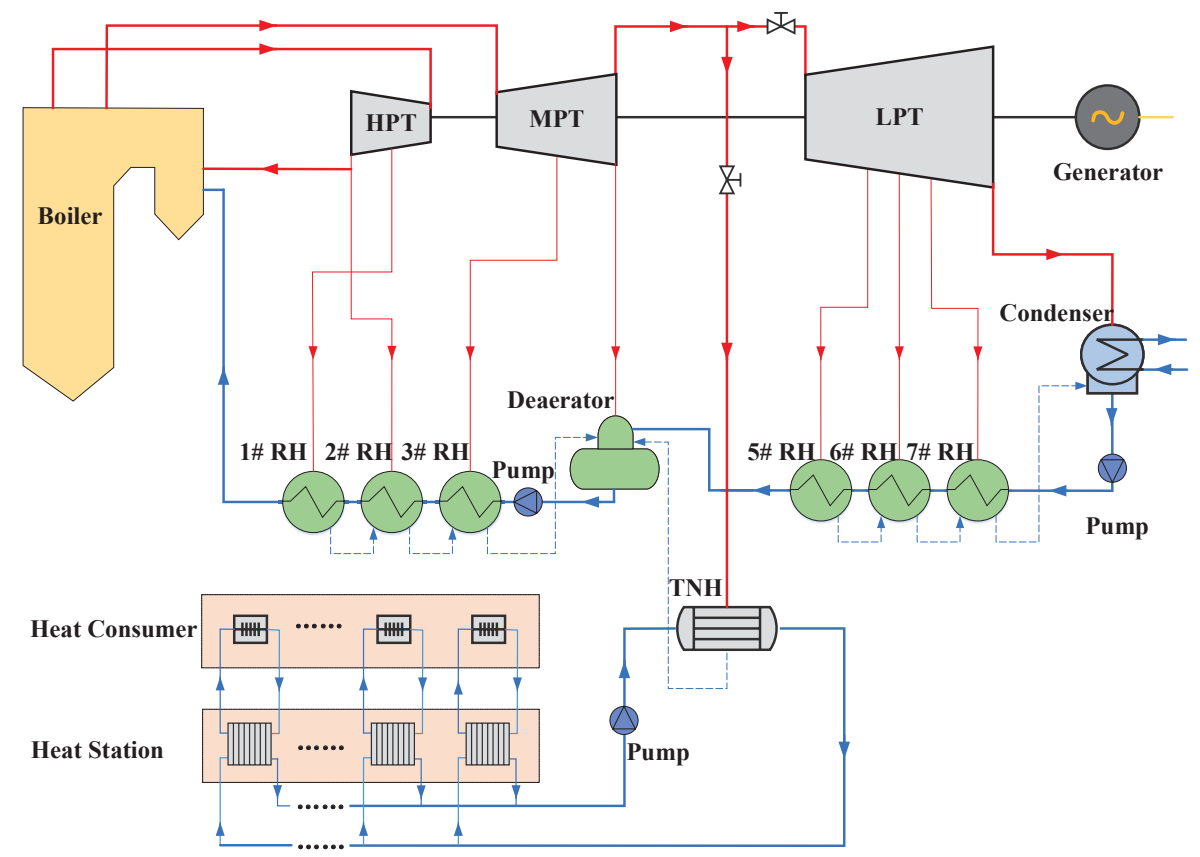

Figure 1. Schematic of the traditional coal-fired CHP-EC system.

The pressure of the extracted steam for heating is 0.4 MPa. After the thermal network heater, the steam is cooled as the drain water of $104{ }^{\circ} \mathrm{C}$ and sent to the deaerator. The maximum mass flow of the extraction steam is $500 \mathrm{t} / \mathrm{h}$. Tables 1 and 2 give the main technical parameters and the steam parameters of the reference system under the turbine maximum continuous rating (TMCR) conditions, respectively. Generally, the turbine heat acceptance (THA) is the normal condition for generation given by the manual of the steam turbine, while the TMCR is the base condition for the CHP process. Table 3 gives the elemental analysis of the selection coal, in which $q_{L H V}, A_{a r}, M_{a r}$ and $V_{a r}$ denote the lower heating value, ash, moisture and volatile contents of the coal as-received, respectively.

However, there are still improvements in the traditional CHP plant: (1) Considering the safety of the LPT, not all the steam can be extracted for heating, which means the exhaust steam loss in the condenser is inevitable. In fact, the volumetric flow rate of the steam in the LPT is usually no less than $1 / 3$ of the designed value. (2) Besides, the energy level of the extracted steam is much higher than that of the thermal network water, which restricts the possibly performance improvement of the traditional CHP plant. 
Table 1. Main technical parameters of the reference power plant.

\begin{tabular}{lcc}
\hline Item & Unit & Value \\
\hline Gross power output (In THA condition) & MW & 300 \\
Gross power output (In TMCR condition) & MW & 322.20 \\
Net power output (In TMCR condition) & MW & 313.42 \\
Mass flow of the coal & $\mathrm{t} / \mathrm{h}$ & 96.43 \\
\hline Efficiencies & & \\
Boiler & $\%$ & 93 \\
Pipeline & $\%$ & 99 \\
Mechanical & $\%$ & 99 \\
Generator & $\%$ & 99 \\
Pump & $\%$ & 83 \\
\hline Pressure losses & & \\
Live steam & $\%$ & 2 \\
Reheat steam & $\%$ & 10 \\
Pipeline from MPT to LPT & $\%$ & 4.5 \\
High-pressure regenerative heater & $\%$ & 3 \\
Low-pressure regenerative heater & $\%$ & 5 \\
\hline
\end{tabular}

Table 2. Steam parameters of the power plant in turbine maximum continuous rating (TMCR) conditions.

\begin{tabular}{lcccc}
\hline Item & Pressure (MPa) & Temperature $\left({ }^{\circ} \mathbf{C}\right)$ & Specific Enthalpy $(\mathbf{k J} / \mathbf{k g})$ & Mass Flow Rate $(\mathbf{t} / \mathbf{h})$ \\
\hline Live steam & 16.67 & 538 & 3397.3 & 1017.92 \\
Reheat steam & 3.58 & 538 & 3535.4 & 846.91 \\
Exhaust steam & 0.014 & 52.57 & 2429.3 & 666.63 \\
1\# RH & 6.20 & 390.4 & 3151.5 & 69.41 \\
2\# RH & 3.98 & 332.6 & 3051.3 & 60.00 \\
3\# RH & 1.90 & 442.7 & 3343.3 & 33.66 \\
Deaerator & 0.98 & 355.9 & 3170.5 & 29.60 \\
5\# RH & 0.63 & 295.4 & 3049.9 & 43.69 \\
6\# RH & 0.26 & 128.56 & 2868.2 & 41.50 \\
7\# RH & 0.89 & 96.32 & 2677.8 & 47.60 \\
\hline
\end{tabular}

Table 3. Elemental analysis of the selected coal.

\begin{tabular}{cccccccccc}
\hline Items & $\boldsymbol{C}_{a r}(\%)$ & $\boldsymbol{H}_{a r}(\%)$ & $\boldsymbol{O}_{a r}(\%)$ & $N_{a r}(\%)$ & $S_{a r}(\%)$ & $A_{a r}(\%)$ & $M_{a r}(\%)$ & $V_{a r}(\%)$ & $q_{L H V}(\mathbf{k J} / \mathbf{k g})$ \\
\hline Value & 73.69 & 4.29 & 2.51 & 2.45 & 1.05 & 6.26 & 9.75 & 23.98 & 29,686 \\
\hline
\end{tabular}

\subsection{CHP System with a High Back-Pressure Turbine}

CHP-HBP is a novel process for the coal-fired power plant, also known as the low vacuum system, as shown in Figure 2 [7]. In the HBP system, the back-pressure of the LPT is increased to improve the energy level of the exhaust steam. Then, the waste heat of the exhaust steam can be recovered to heat the thermal network water. By doing this, the loss of exhaust steam is eliminated and nearly zero loss of the turbine side can be achieved. Thus, the HBP system could significantly improve the heating capacity and efficiency of the power plant [22].

In this research, the back-pressure of the LPT was set as $54 \mathrm{kPa}$ with the saturation temperature of $83.27^{\circ} \mathrm{C}$, by removing the last two stages of blades [23]. Compared with the traditional CHP system, the temperature of the heating steam in the HBP system is much lower. This could reduce the exergy loss between the steam and thermal network water, but make it worse in the adaption to a high-temperature thermal network. However, such characteristics cannot be reflected in the existing energy- and exergy-based evaluation method, because they are all based on the product only and care little about the energy level of the heating steam. In the following part, thermodynamic performances of the two system based on the existing evaluation methods are compared and the limitations are discussed. 


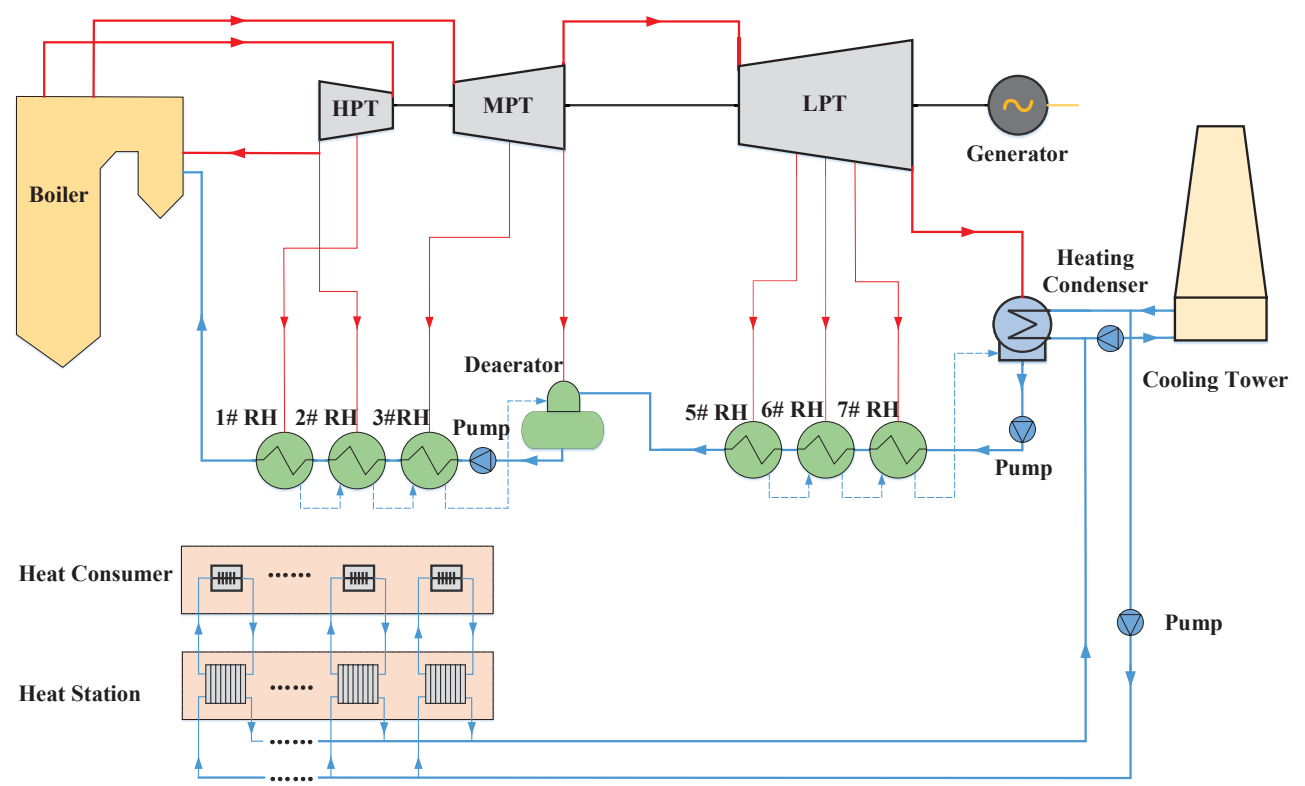

Figure 2. Schematic of the coal-fired CHP-HBP system.

\section{Modeling and Evaluation Criterion}

\subsection{Modeling Method}

In this research, EBSILON Professional was used to building the mathematical model, which is widely used in the design, optimization and evaluation of the general thermal process and has proved to be a reliable tool in modeling process [24,25]. Model details of the main components are listed in Table 4, and the model of the reference system in EBSILON is shown in Figure 3. In the modeling process, the shaft-packing leakage of the turbine is also considered to improve the accuracy. Some of the leakages are recovered to the gland heater $(\mathrm{GH})$, while the others are sent to the seal system of the LPT. Detailed sources and destinations of the leakages can be seen in Figure 3.

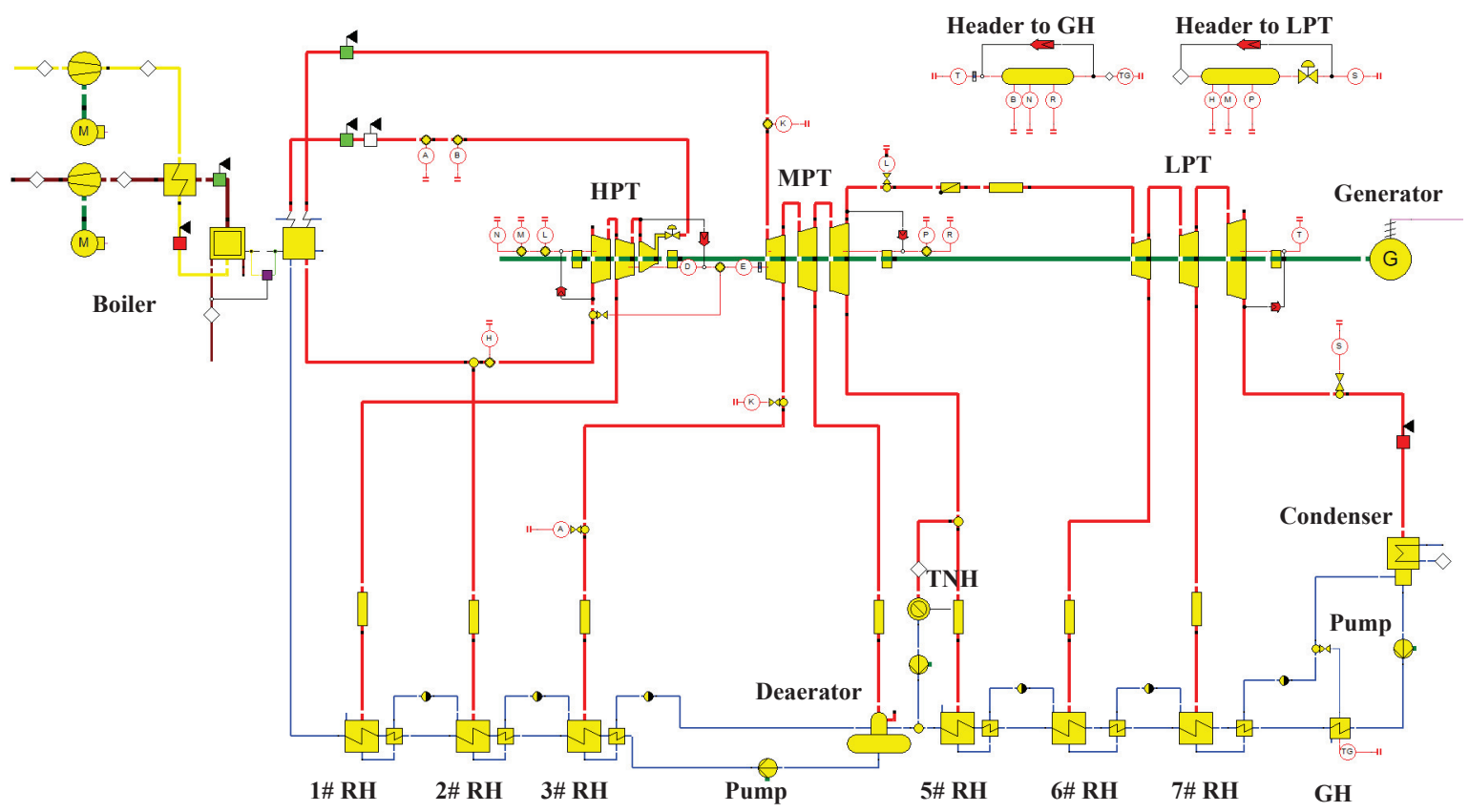

Figure 3. Model of the CHP-EC system in EBSILON Professional. 
Table 4. Model details of the main components in EBSILON Professional.

\begin{tabular}{|c|c|c|}
\hline Component & Module Type & Parameters \\
\hline Boiler & NO. 5 & $\begin{array}{l}\text { Reheat steam temperature }=538{ }^{\circ} \mathrm{C} ; \\
\text { Live steam pressure }=16.67 \mathrm{MPa} ; \\
\text { Live steam pressure loss }=14 \% ; \\
\text { Reheat steam pressure loss }=10 \%\end{array}$ \\
\hline Turbines & NO. 122 & $\begin{array}{l}\text { Isentropic Efficiency = 83.53-93.56\%; } \\
\text { Mechanical Efficiency = 99.8\%; } \\
\text { Heat loss = } 0\end{array}$ \\
\hline Generator & NO. 11 & Electrical efficiency $=99 \%$ \\
\hline Condenser & NO. 7 & $\begin{array}{l}\text { Upper temperature difference }=1^{\circ} \mathrm{C} ; \\
\text { Pressure drop }=5 \mathrm{kPa}\end{array}$ \\
\hline Pump & NO. 8 & $\begin{array}{l}\text { Isentropic Efficiency }=83 \% \\
\text { Mechanical Efficiency }=99.80 \%\end{array}$ \\
\hline Thermal network heater & NO. 35 & $\begin{array}{l}\text { Maximum mass flow }=500 \mathrm{t} / \mathrm{h} \text {; } \\
\text { Dain water temperature }=104{ }^{\circ} \mathrm{C}\end{array}$ \\
\hline Pressure-control & NO. 59 & Pressure for $\mathrm{DH}$ system $\geq 0.4 \mathrm{MPa}$ \\
\hline Pressure losses & NO. 13 & $\begin{array}{l}\text { High-pressure regenerative heater }=3 \% \text {; } \\
\text { Low-pressure regenerative heater }=5 \% \text {; } \\
\text { Pipeline from MPT to LPT }=4.5 \%\end{array}$ \\
\hline Feed water preheater & NO. 10 & $\begin{array}{l}\text { Pressure loss of feed water }=5 \mathrm{kPa} \text {; } \\
\text { Upper temperature difference: } 1 \#=-1.7^{\circ} \mathrm{C} \text {, } \\
2 \# / 3 \#=0{ }^{\circ} \mathrm{C}, 5 \# 7 \#=2.8^{\circ} \mathrm{C}\end{array}$ \\
\hline After cooler & NO. 27 & Lower temperature difference $=5.6^{\circ} \mathrm{C}$ \\
\hline
\end{tabular}

In the off-designed simulation of the turbine, there are two parameters that have substantial influences on the power output: (1) the inlet and outlet pressures and (2) the isentropic efficiency.

In EBSILON professional, the pressures can be deduced by Stodola's law [26]:

$$
\text { Const }=G \sqrt{\frac{v}{p}}
$$

where $G$ is the mass flow rate the steam, $\mathrm{kg} / \mathrm{h} ; p$ is the inlet pressure, MPa; $v$ denotes the specific volume, $\mathrm{m}^{3} / \mathrm{kg}$.

The output of the turbine stage $\left(P_{s}\right)$ can be calculated as:

$$
P_{s}=G\left(h_{1}-h_{2, i s}\right) \eta_{i s} \eta_{s, m}
$$

where $h_{1}$ and $h_{2, i s}$ are the enthalpies of the inlet steam and outlet steam in isentropic process, $\mathrm{kJ} / \mathrm{kg}$; $\eta_{i s}$ and $\eta_{s, m}$ denote the isentropic efficiency and mechanical efficiency, which are obtained in the manual of the steam turbine, $\%$.

Figure 4 gives the accuracy validation of the model, which compares the simulation results of the model with design data of the turbine manual in both power-only and CHP conditions. The maximum relative error(RE) is $-0.39 \%$ in $75 \%$ THA condition, which proves that the model has high precision and can be used in the following discussion. 


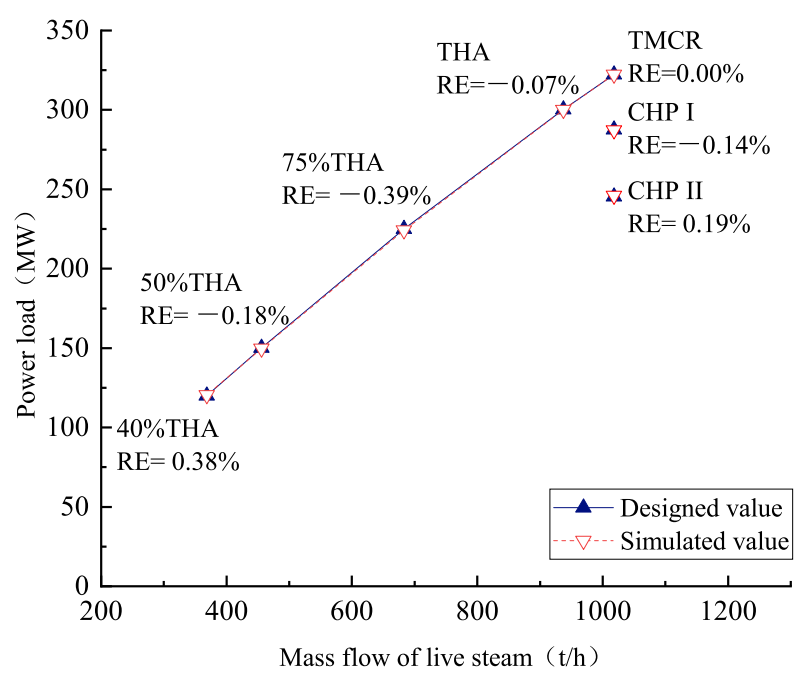

Figure 4. Comparison between simulation results and design data.

\subsection{Evaluation Criterion}

\subsubsection{Energy-Based Evaluation}

The most commonly used evaluation method of the CHP system is based on the first law of thermodynamics, called the energy-based evaluation [27]. This method mainly follows the mass and energy balances and can obtain primary energy savings. The typical indicators are given below.

The gross thermal efficiency $\left(\eta_{g, C H P}\right)$ :

$$
\eta_{g, C H P}=\frac{P+Q_{H}}{B q_{L H V} / 3600} \times 100 \%
$$

where $P$ and $Q_{H}$ are the power and heat loads of the CHP system, respectively, MW; $B$ is the coal consumption rate of the boiler, $\mathrm{t} / \mathrm{h}$.

The heating efficiency $\left(\eta_{h, C H P}\right)$ :

$$
\eta_{h, \mathrm{CHP}}=\eta_{b, \mathrm{CHP}} \eta_{p, \mathrm{CHP}}
$$

where $\eta_{b, C H P}$ and $\eta_{p, C H P}$ are the efficiencies of the boiler and pipe, $\%$.

The generation efficiency $\left(\eta_{e, C H P}\right)$ :

$$
\eta_{e, C H P}=\frac{P}{B q_{L H V}-Q_{H} / \eta_{h, C H P}} \times 100 \%
$$

The standard coal consumption rate of generation $\left(b_{e, C H P}\right)$ :

$$
b_{e, C H P}=\frac{122.8}{\eta_{e, C H P}}
$$

The standard coal consumption rate of heating $\left(b_{h, C H P}\right)$ :

$$
b_{h, \mathrm{CHP}}=\frac{34.1}{\eta_{h, \mathrm{CHP}}}
$$

\subsubsection{Conventional Exergy-Based Evaluation}

The energy-based evaluation presents the energy utilization condition from the quantity aspect, but ignores the energy level differences of the sources and products. By contrast, the exergy is a conception based on the second law of thermodynamics. It represents the maximum useful work the 
energy can generate with its environment during a reversible process, and is the measure of the energy quality. The exergy efficiency can be usually defined as the ratio of useful exergy output to the total exergy input. Hence, exergy-based evaluation covers not only the quantity but also the quality of the energy and is considered as a more objective criterion than the energy-based method [28].

The traditional exergy efficiency of the CHP system can be given as:

$$
\eta_{g, C H P}^{e x}=\frac{P+E_{H}}{B q_{L H V} \xi} \times 100 \%=\frac{P+Q_{H} \eta_{D H}^{e x}}{B q_{L H V} \xi} \times 100 \%
$$

where $E_{H}$ is the output exergy for heating, MW; $\xi$ is the ratio of the exergy of the coal to its $q_{L H V}$; $\eta_{D H}^{e x}$ is the exergy efficiency of the DH system, \%.

$\xi$ can be calculated as [29]:

$$
\xi=1.009+\frac{0.131 O_{a r}+0.16 M_{a r}}{1-\left(A_{a r}+M_{a r}\right)}
$$

The $\eta_{D H}^{e x}$ can be calculated as:

$$
\eta_{D H}^{e x}=1-\frac{T_{0}+273.15}{T_{C}+273.15} \times 100 \%
$$

where $T_{0}$ and $T_{C}$ are the temperatures of the environment and the cold-end, ${ }^{\circ} \mathrm{C}$. In this study, the temperature of the environment was set as $0^{\circ} \mathrm{C}$. In traditional exergy-based evaluation, the cold-end has different definitions. Usually, the object of the cold-end could be the heat consumer or the heat station. In this research, $T_{C}$ of the former was constant as $20^{\circ} \mathrm{C}$ while $T_{C}$ of the latter was the mean temperature of the supplied- and returned-water, ${ }^{\circ} \mathrm{C}$.

\section{Results and Discussion}

\subsection{Traditional Energy-Based and Exergy-Based Evaluations}

\subsubsection{Thermodynamic Performance in Design Conditions}

Figure 5 gives the energy flow diagram of the two systems in the maximum heating condition. The energy from the boiler of the HBP system is $1.87 \mathrm{MW}$ lower than the EC system when the mass flow of the main steam remains the same. The main losses of the EC system from the condenser, boiler, pipes and others, account for $17.72 \%, 7 \%, 1.35 \%$ and $0.35 \%$ of the input energy, respectively. Moreover, the output heating and power occupy $43.83 \%$ and $29.74 \%$, respectively. Compared with the EC system, the HBP system has a similar energy loss distribution except for the exhaust steam loss, which is 0 in the HBP system. The output heating and power of the HBP system account for $55.61 \%$ and $35.63 \%$, $11.78 \%$ and $5.89 \%$ higher values than those of the EC system.

Table 5 gives the energy-based comparison of the two CHP modes in design conditions. The HBP system has higher heating capacity, power output, generation efficiency and exergy efficiency than the EC system. In detailed, the gross efficiencies of the HBP system reach $91.24 \%$ and $17.67 \%$ higher than the EC system. Moreover, the heating capacity of the HBP system also has a $26.58 \%$ (92.89 MW) improvement over that of the EC system. In the meantime, the power generated by the HBP system is also 46.29 MW higher. Overall, the generation efficiency of the HBP system reaches $89.98 \%$ with the standard coal consumption rate of $136.47 \mathrm{~g} / \mathrm{kWh}, 79.84 \mathrm{~g} / \mathrm{kWh}$ lower than that of the EC system. When the temperature of the cold end is set as the heat user $\left(T_{C}=20^{\circ} \mathrm{C}\right)$, the exergy efficiency of the HBP system is $6.52 \%$ higher than that of the EC system. 


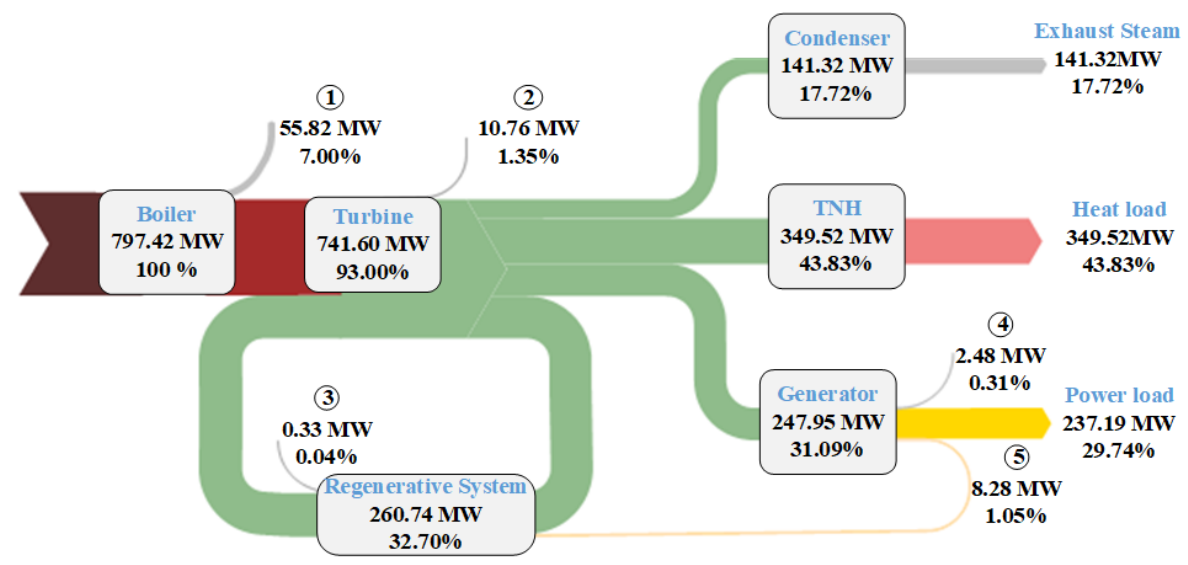

(a)

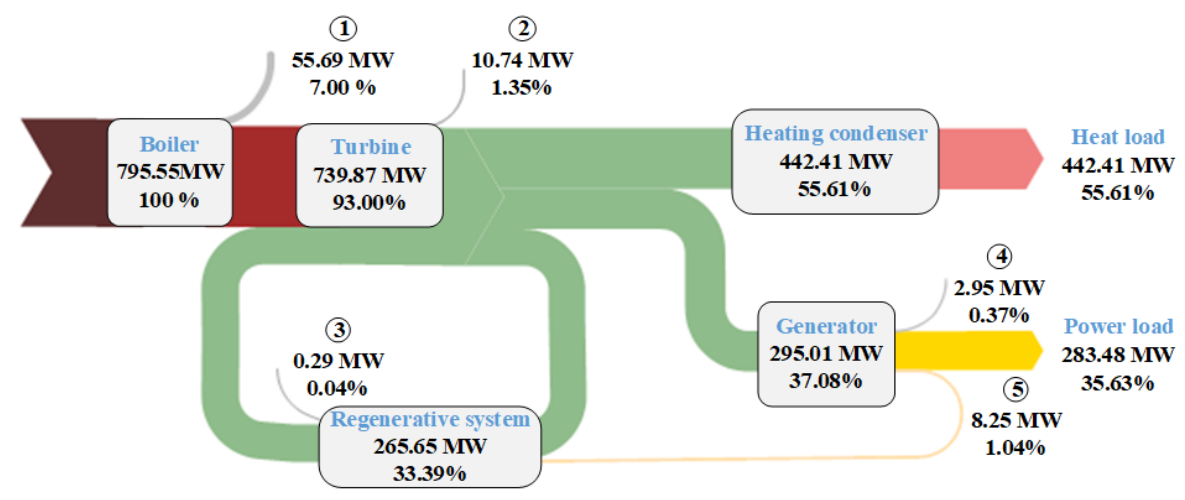
(1) Loss of the boiler
(2) Loss of steam turbines
(3) Loss of the regenerative system
(4) Loss of the Generator
(5) Power consumption of the regenerative system

(b)

Figure 5. Energy flow of the CHP systems: (a) EC system; (b) HBP system.

Table 5. Thermodynamic performances of the two CHP systems in design conditions.

\begin{tabular}{lcccc}
\hline Items & Unit & EC System & HBP System & Differences \\
\hline Energy of the coal & $\mathrm{MW}$ & 797.42 & 795.55 & - \\
Pressure of the heating steam & $\mathrm{kPa}$ & 400 & 54 & - \\
Mass flow of the heating steam & $\mathrm{t} / \mathrm{h}$ & 500 & 703.78 & - \\
Temperature of the heating steam & $\mathrm{C}$ & 145.87 & 83.27 & - \\
Heating capacity & $\mathrm{MW}$ & 349.52 & 442.41 & 92.89 \\
Generation power & $\mathrm{MW}$ & 237.19 & 283.48 & 46.29 \\
Generation efficiency $\left(\eta_{e, \mathrm{CHP}}\right)$ & $\%$ & 56.77 & 89.98 & 33.21 \\
Coal consumption rate for generation $\left(b_{e, C H P}\right)$ & $\mathrm{g} / \mathrm{kWh}$ & 216.30 & 136.47 & -79.84 \\
Heating efficiency $\left(\eta_{h, \mathrm{CHP}}\right)$ & $\%$ & 92.07 & 92.07 & 0.00 \\
Coal consumption rate for heating $\left(b_{h, \mathrm{CHP}}\right)$ & $\mathrm{kg} / \mathrm{GJ}$ & 37.04 & 37.04 & 0.00 \\
Gross thermal efficiency $\left(\eta_{g, C H P}\right)$ & $\%$ & 73.58 & 91.24 & 17.67 \\
Exergy efficiency of $\mathrm{DH}$ system $\left(\eta_{D H}^{e x}\right)\left(T_{C}=20{ }^{\circ} \mathrm{C}\right)$ & $\%$ & 6.82 & 6.82 & 0.00 \\
Exergy efficiency $\left(\eta_{g, \mathrm{CHP}}^{\text {ex }}\right)\left(T_{C}=20^{\circ} \mathrm{C}\right)$ & $\%$ & 31.89 & 38.41 & 6.52 \\
\hline
\end{tabular}

\subsubsection{Efficiencies under the Off-Design Conditions}

Figure 6 shows the gross thermal efficiencies, generation efficiencies and exergy efficiencies of the two systems in the whole feasible operational range. It can be seen that the energy-based evaluation methods $\left(\eta_{g, C H P}\right.$ and $\left.\eta_{e, C H P}\right)$ show similar trends, which are that $\eta_{g, C H P}$ and $\eta_{e, C H P}$ will increase with the increment of the heat load when the live steam remains the same. With the maximum mass flow of live steam, when the heat load of the EC system changes from 0 to $249.52 \mathrm{MW}, \eta_{g}, \mathrm{CHP}$ and $\eta_{e, C H P}$ are 
increased from $39.83 \%$ to $73.58 \%$ and from $39.83 \%$ to $56.77 \%$, respectively. By contrast, when the heat load of the HBP system changes from 0 to $442.41 \mathrm{MW}, \eta_{g, \mathrm{CHP}}$ and $\eta_{e, \mathrm{CHP}}$ are increased from $35.70 \%$ to $91.24 \%$ and from $35.70 \%$ to $89.98 \%$, respectively. This trend also reflects the advantage of the CHP system over the power-only system. However, a different trend is achieved when it comes to $\eta_{g, C H P}^{e x}$. The rise of the heat load could decrease $\eta_{g, C H P}^{e x}$ of the EC system but increase $\eta_{g, C H P}^{e x}$ of the HBP system. When the heat load changes from 0 to the maximum, $\eta_{g, C H P}^{e x}$ of the EC system decreases from $38.81 \%$ to $31.89 \%$ when $\eta_{g, C H P}^{e x}$ of the HBP system increases from $34.78 \%$ to $38.41 \%$. Furthermore, results in Figure $6 \mathrm{c}, \mathrm{f}$ also are affected by the cold-end temperature, which brings about some limitations which are discussed in Sections 4.1.3 and 4.2.

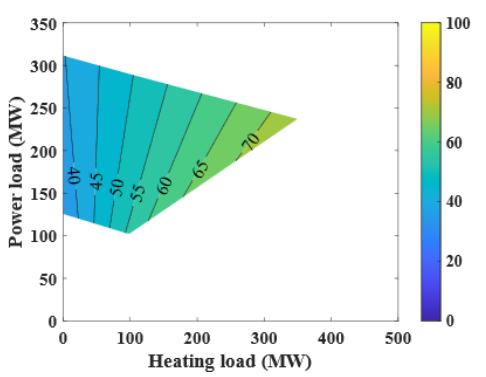

(a)

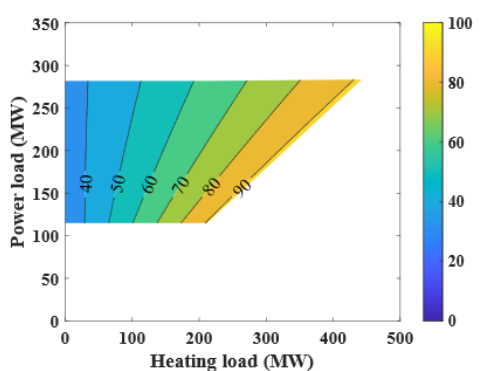

(d)

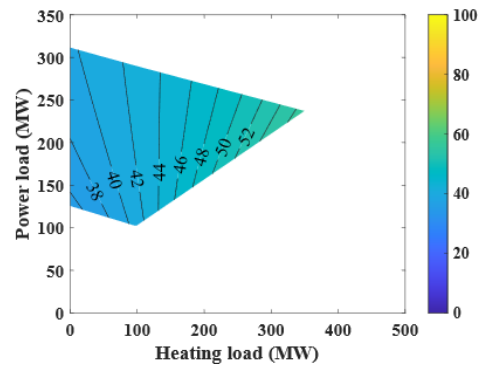

(b)

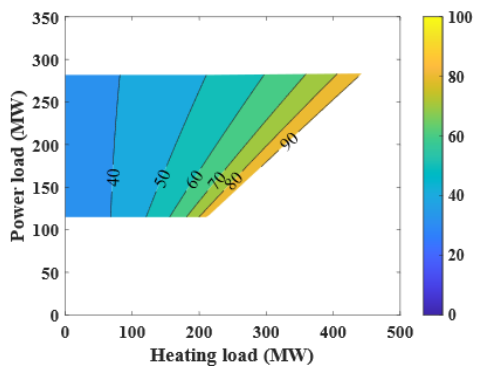

(e)

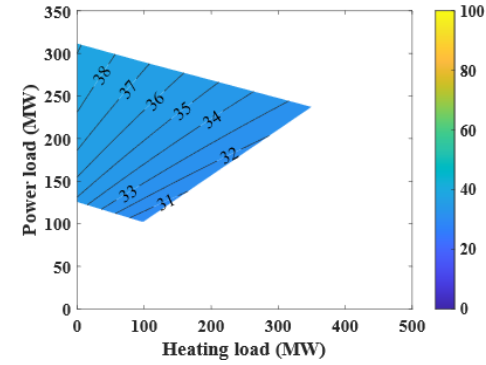

(c)

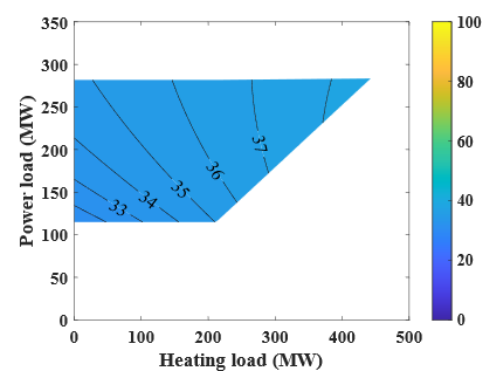

(f)

Figure 6. Efficiencies in the feasible operational region: (a) $\eta_{g, \mathrm{CHP}}$ of EC system; (b) $\eta_{e, \mathrm{CHP}}$ of EC system; (c) $\eta_{g, C H P}^{e x}$ of EC system $\left(T_{C}=20^{\circ} \mathrm{C}\right) ;(\mathbf{d}) \eta_{g, C H P}$ of HBP system; (e) $\eta_{e, C H P}$ of HBP system; (f) $\eta_{g, \mathrm{CHP}}^{\text {ex }}$ of $\mathrm{HBP}$ system $\left(T_{\mathrm{C}}=20^{\circ} \mathrm{C}\right)$.

\subsubsection{Exergy Analysis with Different Cold-End Temperatures}

According to Equation (10), the conventional exergy-based evaluation is based not only on the CHP system but also on the temperature of the cold end. In the above section, the cold end is set as the heat user $\left(T_{C}=20^{\circ} \mathrm{C}\right)$. In this section, the cold end is the water in the DH system. Moreover, the temperatures of the returned-and supplied-water could influence the exergy-based performance. Figure 7 shows the influences of returned-and supplied-water temperatures on $\eta_{D H}^{e x}$. In the application, the temperatures of returned- and supplied-water are usually no more than $70 / 130^{\circ} \mathrm{C}$. Temperatures higher than these are for the theoretical analysis only and are presented as empty circles in the figure.

With the increment of the returned-and supplied-water temperatures, the exergy of the DH system increases. With the mean temperature of the water increases from $35^{\circ} \mathrm{C}$ to $125^{\circ} \mathrm{C}, \eta_{D H}^{e x}$ is raised from $11.36 \%$ to $31.40 \%$, which means every $10{ }^{\circ} \mathrm{C}$ improvement of the mean temperature could bring about $2.23 \%$ increment of $\eta_{D H}^{e x}$ in the given temperature range. With the returned-and supplied-water temperatures of $70 / 130{ }^{\circ} \mathrm{C}, \eta_{D H}^{e x}$ could reach $26.80 \%$.

Based on $\eta_{D H}^{e x}$ given in Figure 7, Figure 8 gives the exergy efficiencies of the two systems with different returned- and supplied-water temperatures. The exergy efficiency has a similar trend as $\eta_{D H}^{e x}$, and increases with the improvement of the mean temperature of the thermal network water. Every $10^{\circ} \mathrm{C}$ improvement of the mean temperature could bring about $1.38 \%$ increment of the exergy efficiency of the 
HBP system, which is $0.95 \%$ of the EC system. Compared with the EC system, the exergy efficiency of the HBP system is $7.04-8.21 \%$ higher with the same cold-end temperature.

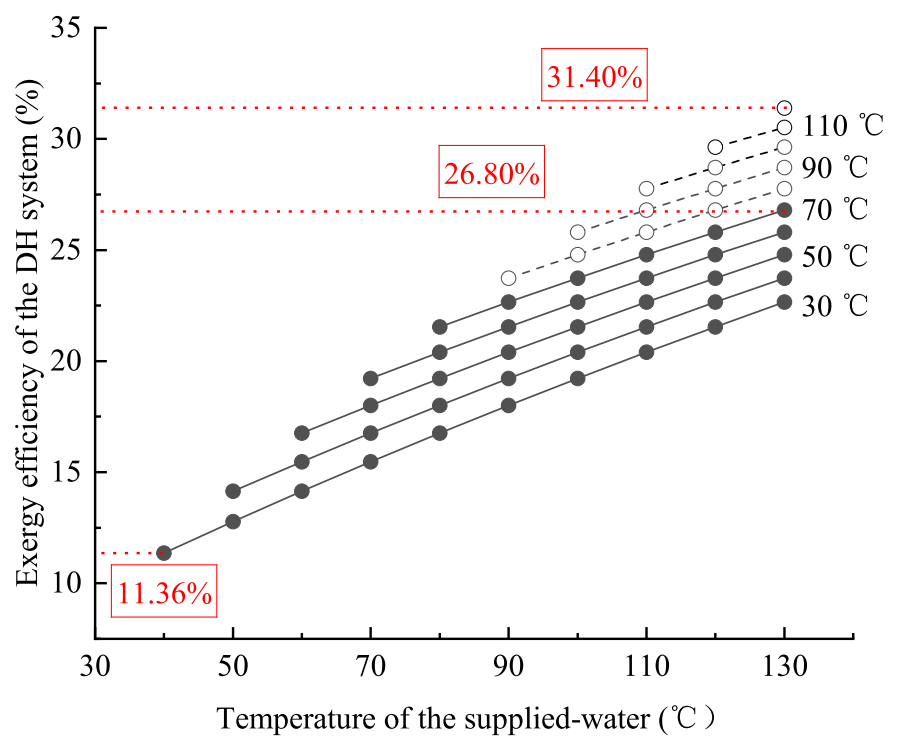

Figure 7. Influences of returned- and supplied-water temperatures on $\eta_{D H}^{e x}$.

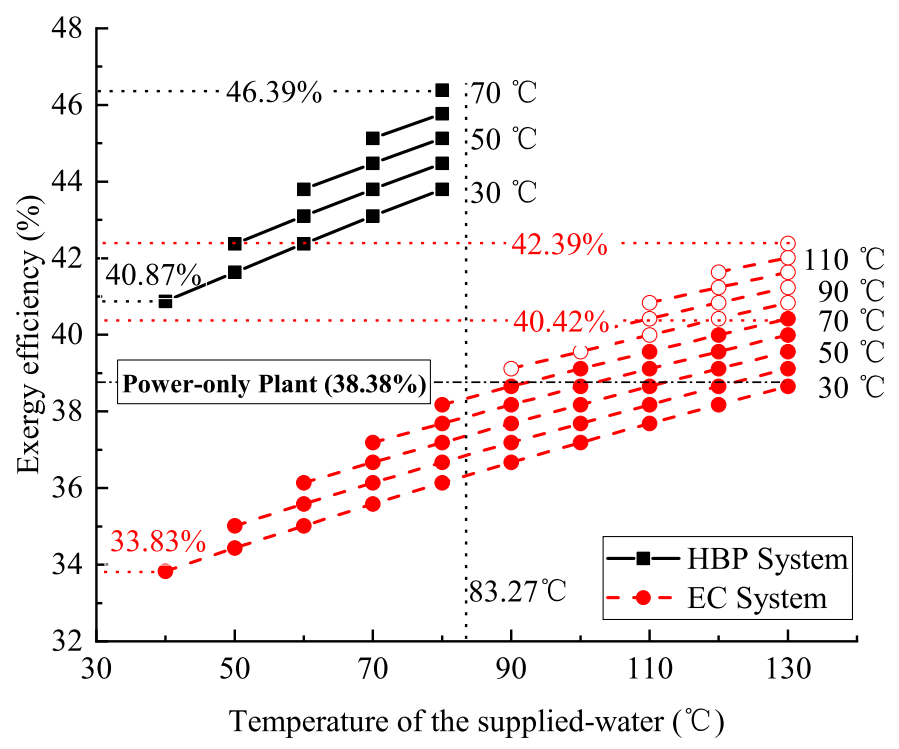

Figure 8. Influences of returned- and supplied-water temperatures on $\eta_{g, C H P}^{e x}$.

\subsection{Novel Exergy-Based Evaluation}

\subsubsection{Limitations of the Traditional Evaluations}

Results above show some limitations of the traditional exergy-based evaluation:

1. The conventional exergy-based evaluation of the CHP system strongly relies on the temperatures of the cold-end and the environment, which increases the complexity of further exergy-based research. For example, each cold-end temperature will need a unique diagram to show the exergy efficiencies in the feasible operational region (Figure $6 c, f)$.

2. The conventional exergy-based evaluation only concerns the product but ignores the heat sources. For example, the HBP system shows great advantages over the EC system under both the energy-based and the conventional exergy-based evaluations. However, the heating steam of 
the EC system has a higher level, which is hard to be displayed in these evaluations. Thus, these evaluation methods have limitations when used to compare different types of CHP systems.

3. Results based on conventional exergy-based evaluation could also lead in the wrong directions. For example, according to the results in Figures 7 and 8, the increment of the cold-end temperature could increase the exergy efficiency of the $\mathrm{CHP}$ system. However, this may raise the bar to recover the low-level waste heat and is opposite to the DH system in the future [30].

\subsubsection{Proposal of the Novel Exergy-Based Evaluation}

The conventional exergy-based evaluation of the CHP system has some limitations and has difficulties in guiding the improvement of CHP technology. Considering that, a novel exergy-based evaluation is proposed in this research, which is based on the exergy consumption dispatch of the heat and power.

In the novel evaluation, the main objective is to separate the exergy consumption of heating from the gross consumption scientifically. After that, the exergy consumption of the generation can be obtained, as shown in Figure 9. The new evaluation concerns the heating steam and its exergy consumption of different CHP types, so the temperatures will not influence it. The following gives the main criterion of the novel evaluation method.

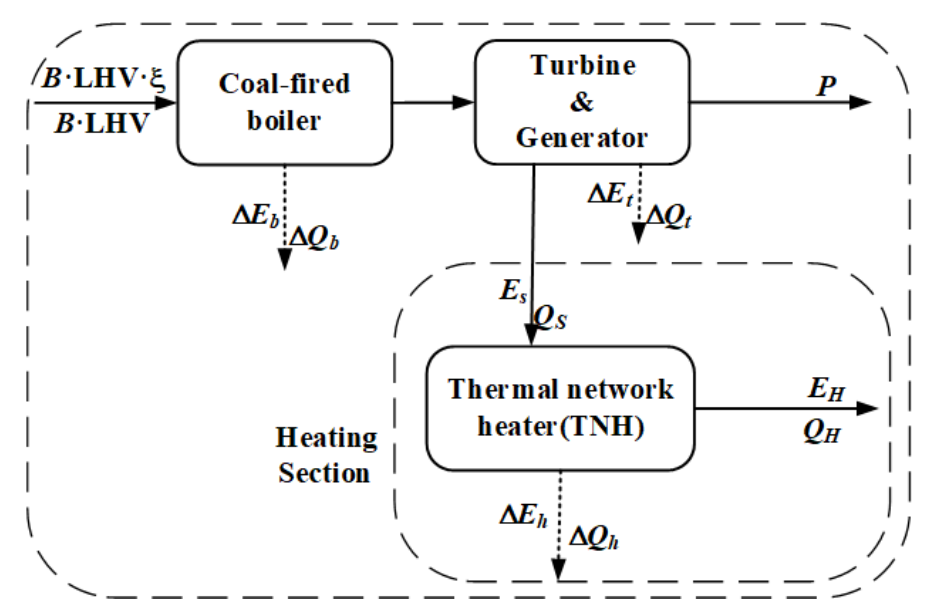

Figure 9. Diagram of energy and exergy flows of the CHP system.

For the thermal network heater (TNH), the exergy efficiency can be achieved as:

$$
\eta_{T N H, C H P}^{e x}=\frac{E_{H}}{E_{S}} \times 100 \%=\frac{1-\left(T_{0}+273.15\right) /\left(T_{C}+273.15\right)}{1-\left(T_{0}+273.15\right) /\left(T_{S}+273.15\right)} \times 100 \%
$$

where $E_{S}$ and $T_{S}$ are the exergy and mean temperature of the heating steam, respectively.

The exergy efficiency for heating $\left(\eta_{h, \mathrm{CHP}}^{e x}\right)$ :

$$
\eta_{h, \mathrm{CHP}}^{e x}=\eta_{\mathrm{TNH}, \mathrm{CHP}}^{e x} \eta_{b, \mathrm{CHP}}^{e x} \eta_{p, \mathrm{CHP}}^{e x}
$$

where $\eta_{p, C H P}^{e x}$ is the exergy efficiencies of the pipe, which is $97 \%$ in this study [31]; and $\eta_{b, C H P}^{e x}$ denotes the exergy efficiency of the boiler, which can be calculated as:

$$
\eta_{b, \mathrm{CHP}}^{\text {ex }}=\frac{D_{0}\left(e_{0}-e_{f}\right)+D_{r}\left(e_{r, h o t}-e_{r, \text { cold }}\right)}{B q_{L H V} \xi} \times 100 \%
$$

where $D_{0}$ and $D_{r}$ are the mass flows of the live steam and reheat steam, $\mathrm{t} / \mathrm{h} ; e_{0}, e_{f}, e_{r, h o t}$ and $e_{r, \text { cold }}$ are the specific exergies of the live steam, feed water, hot and cold sides of the reheat steam, respectively, $\mathrm{kJ} / \mathrm{kg}$. 
Finally, the exergy efficiency for the generation $\left(\eta_{e, C H P}^{e x}\right)$ of the EC system can be deduced:

$$
\eta_{e, \mathrm{CHP}}^{e x}=\frac{P}{B q_{L H V} \xi-E_{H} / \eta_{h, \mathrm{CHP}}^{e x}} \times 100 \%
$$

For the HBP system, the mass flow of the exhaust steam depends on the mass flow of live steam only. That means when the live steam is constant, the exergy consumption for heating should be the same no matter whether the waste heat of the exhaust steam is fully recovered. Here, $\tau$ is defined as the mass flow ratio of the exhaust steam recovered in the heating condenser. Then, the exergy consumption for heating should be $E_{H} /\left(\eta_{h, C H P}^{e x} \tau\right)$, and the $\eta_{e, C H P}^{e x}$ of the HBP system is deduced as:

$$
\eta_{e, \mathrm{CHP}}^{e x}=\frac{P}{B q_{L H V} \xi-E_{H} /\left(\eta_{h, \mathrm{CHP}}^{e x} \tau\right)} \times 100 \%
$$

\subsubsection{Exergy Analysis under Design Conditions}

To show the energy level differences between the heating steam in the two systems, Figure 10 gives the $T-Q$ diagram of the heating steam in the two systems. The heating steam of the EC system goes through several states (superheated steam, saturated steam, wet steam, saturated water, unsaturated water) in the heating process with the mean temperature of $145.87^{\circ} \mathrm{C}$. By contrast, the heating steam of the HBP system is wet steam initially, and releases heat to the saturated water with a constant temperature of $83.27^{\circ} \mathrm{C}$. Thus, although the heating capacity of the HBP system is $72.89 \mathrm{MW}$ higher, the energy level of the heating steam is lower than that of the EC system.

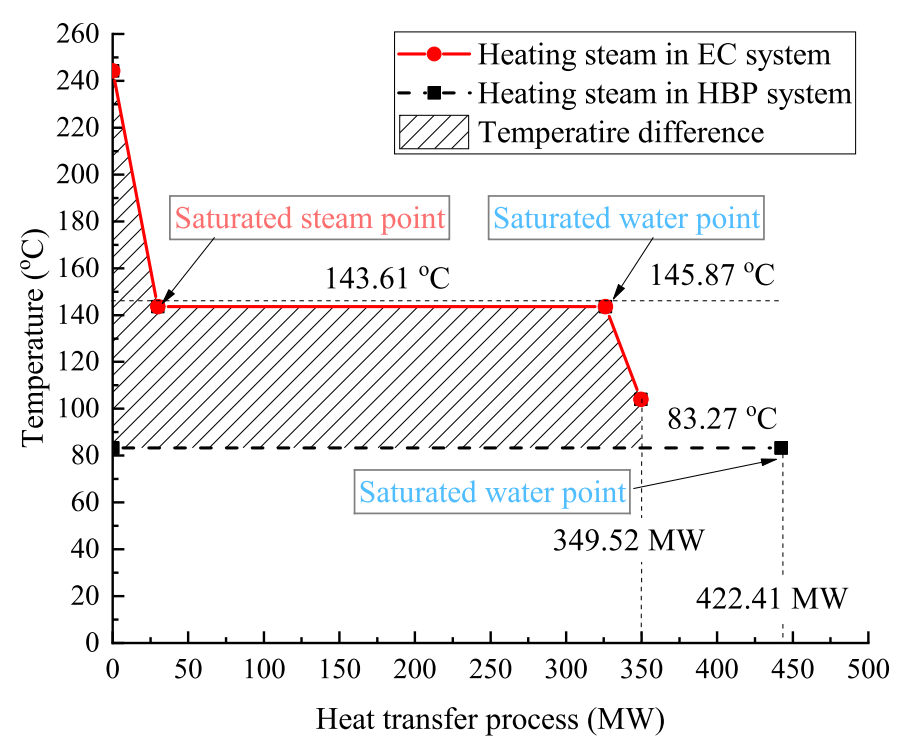

Figure 10. $T-Q$ diagram of the heating steam.

Figure 11 gives the influences of the supplied- and returned water temperatures on the exergy efficiency of the TNH. Similar to the gross exergy efficiency shown in Figure 9, the improvement of the temperature of the thermal network water can increase $\eta_{T N H, C H P}^{e x}$ in both systems. With the same supplied-and returned water temperatures, the $\eta_{T N H, C H P}^{e x}$ of the HBP system is $16.00-30.32 \%$ higher than that of the EC system. Within the given range, the $\eta_{T N H, C H P}^{e x}$ of the HBP system can reach $92.21 \%$ $\left(80 / 70{ }^{\circ} \mathrm{C}\right)$, which is $76.98 \%\left(130 / 70{ }^{\circ} \mathrm{C}\right)$ of the EC system. 


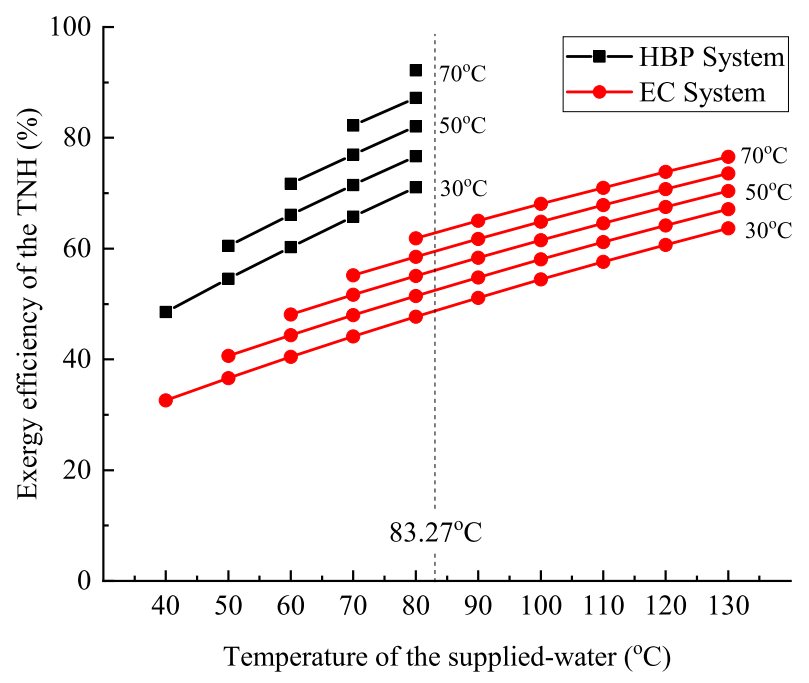

Figure 11. Influences of the returned- and supplied-water temperatures on $\eta_{T N H, C H P}^{e x}$.

Based on the results in Figure 11, Figure 12 shows the influence of the thermal network heater temperature on the exergy efficiency for heating $\left(\eta_{h, \mathrm{CHP}}^{e x}\right)$. The exergy efficiency of the boiler was calculated to be $51.14 \%$, and the exergy efficiency of the pipes was set as $97 \%$. With the returned-water temperature increasing from $30{ }^{\circ} \mathrm{C}$ to $70{ }^{\circ} \mathrm{C}$, the $\eta_{h, \mathrm{CHP}}^{e x}$ of the EC system changed from $32.71 \%$ to $38.70 \%$ with the supplied-water temperature of $130{ }^{\circ} \mathrm{C}$; that of the HBP system changed from $36.06 \%$ to $46.35 \%$ with the supplied-water temperature of $80^{\circ} \mathrm{C}$.

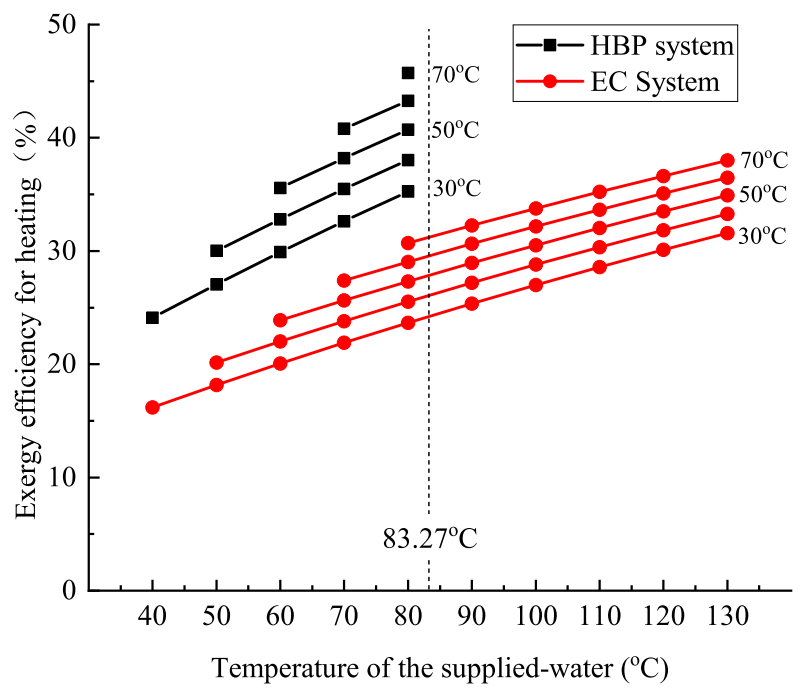

Figure 12. Influences of the returned- and supplied-water temperatures on $\eta_{h, C H P}^{e x}$.

Then the thermodynamic comparison based on the novel exergy analysis is shown in Table 6. According to the results before, the energy of the heating steam of the HBP system is $72.89 \mathrm{MW}$ higher than that of the EC system. However, the exergy of the heating steam of the HBP system is $18.32 \mathrm{MW}$ lower than that of the EC system, which is caused by the energy difference of the heating steam and also leads to a $33.30 \mathrm{MW}$ decrement of the exergy consumption for heating. Finally, the exergy efficiencies for generation $\left(\eta_{e, C H P}^{e x}\right)$ of the HBP system and EC system can be achieved, which are $46.48 \%$ and $41.22 \%$, respectively. Compared with the power-only system, the $\eta_{e, C H P}^{e x}$ of the HBP system and EC system are $8.10 \%$ and $2.84 \%$ higher. 
Table 6. Novel exergy analysis of the systems.

\begin{tabular}{lcccc}
\hline Items & Unit & Power-Only System & EC System & HBP System \\
\hline Exergy of the coal & MW & 816.64 & 818.48 & 816.55 \\
Exergy to the live and reheat steam & MW & 423.19 & 424.14 & 423.15 \\
Exergy of the heating steam & MW & - & 121.68 & 103.36 \\
Exergy consumption for heating & MW & - & 241.64 & 208.34 \\
Net generation power & MW & 313.42 & 237.19 & 283.48 \\
Exergy efficiency for generation & $\%$ & 38.38 & 41.22 & 46.48 \\
\hline
\end{tabular}

Figure 13 gives the $\eta_{e, C H P}^{e x}$ in the feasible operational region of the EC system and HBP system. Then, three features of the novel exergy-based evaluation can be deduced by comparing with the results in Figure 6e,f: (1) $\eta_{e, \mathrm{CHP}}^{e x}$ and $\eta_{g, \mathrm{CH} P}^{e x}$ are the same when the heat load is 0 . Since in this condition the CHP plant can be considered as the power-only system, $\eta_{e, C H P}^{e x}$ and $\eta_{g, C H P}^{e x}$ will be not influenced by the heating part. (2) With the increment of the heat load, different trends are achieved. For the EC system, with the live steam mass flow unchanged, the $\eta_{e, C H P}^{e x}$ is increased with the improvement of the heat load, when $\eta_{g, C H P}^{e x}$ is decreased in the same condition. For the HBP system, the $\eta_{e, C H P}^{e x}$ remains unchanged with the same mass flow of the live steam. In this condition, the change of the heat load only influences the heat dispatch of the heating condenser and cooling tower, not the coal consumption and generation characters. Thus, the trend of $\eta_{e, C H P}^{e x}$ can reflect the characters of the CHP system clearer than $\eta_{g, C H P}^{e x}$. (3) Since $\eta_{e, C H P}^{e x}$ is based on the exergy consumption dispatch of the heat and power concerning more regarding the $\mathrm{CHP}$ system itself, the cold-end temperature has no influence on the results in Figure 13. With these features, the novel exergy-based evaluation is supplementary to the existing evaluation system.

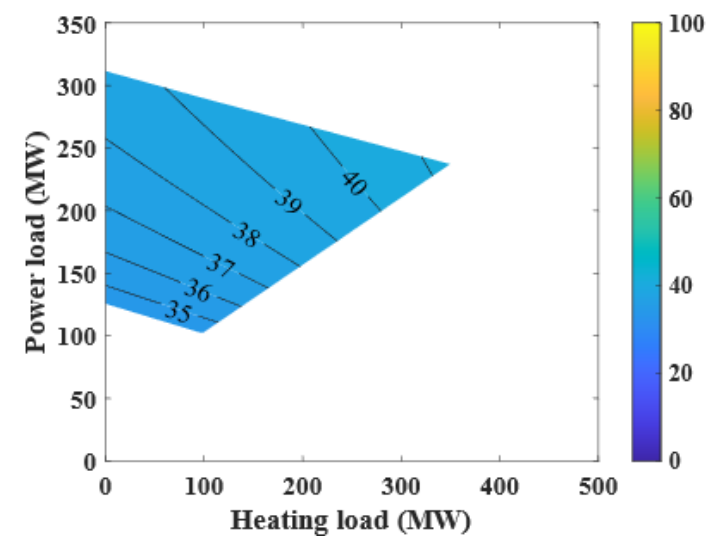

(a)

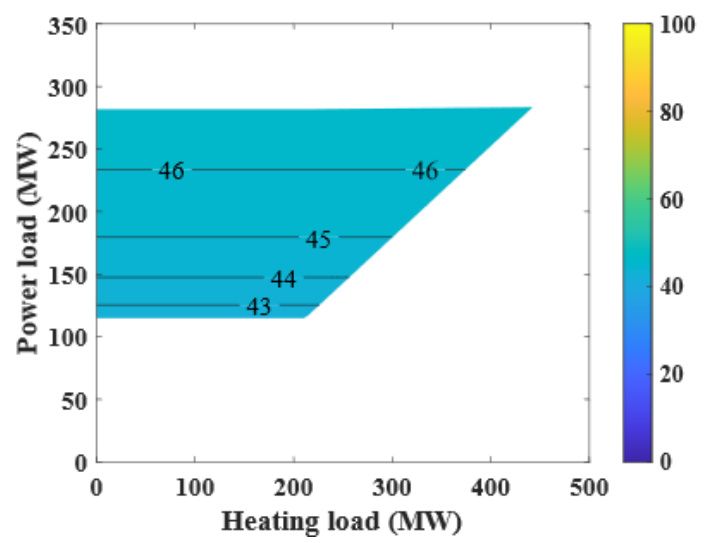

(b)

Figure 13. $\eta_{e, C H P}^{e x}$ in the feasible operational region: (a) EC system; (b) HBP system.

\section{Conclusions}

In this study, a comprehensive thermodynamic performance evaluation of the coal-fired CHP plant with a HBP turbine was performed based on both the energy- and exergy-based evaluation methods. Compared with the traditional CHP plant with EC mode, the thermodynamic characteristics of the HBP system under full operational conditions were obtained. Then, considering the energy level differences of the heating steam, a novel exergy-based evaluation method was proposed and applied to compare the performances of different CHP systems. The main results were as follows:

(1) In design conditions, both the heating capacity and power output of the HBP system were higher than those of the EC system, which led to $17.67 \%$ and $33.21 \%$ increments of the gross thermal efficiency and generation efficiency respectively, and a $79.84 \mathrm{~g} / \mathrm{kWh}$ decrement of the standard coal 
consumption rate. Compared with the EC system, the exergy efficiencies of the HBP system were $7.04-8.21 \%$ higher with the same cold end temperature.

(2) Efficiencies in the feasible operational region were also achieved and show that the energy-based evaluation methods $\left(\eta_{g, \mathrm{CH} P}\right.$ and $\left.\eta_{e, \mathrm{CHP}}\right)$ show similar trends: $\eta_{g, \mathrm{CH} P}$ and $\eta_{e, \mathrm{CHP}}$ will increase with the increment of the heat load when the live steam remains the same, while $\eta_{g, C H P}$ will show the opposite trend.

(3) According to the novel exergy-based evaluation method, the exergy efficiencies for the generation $\left(\eta_{e, C H P}^{e x}\right)$ of the HBP system and EC system were $46.48 \%$ and $41.22 \%$, respectively- $8.10 \%$ and $2.84 \%$ higher than those of the power-only system. $\eta_{e, C H P}^{e x}$ in the whole feasible operational region was obtained.

Author Contributions: Conceptualization, S.Z. and Z.G.; methodology, S.Z.; software, S.Z.; validation, S.Z., Z.G. and W.W.; formal analysis, S.Z.; investigation, S.Z. and Z.G.; resources, W.W.; data curation, W.W.; writing — original draft preparation, S.Z. and W.W.; writing - review and editing, S.Z. and W.W.; visualization, S.Z. and W.W.; supervision, W.W. and Z.G.; project administration, W.W.; funding acquisition, W.W. and S.Z. All authors have read and agreed to the published version of the manuscript.

Funding: This research was funded by the Science and Technology Innovation Team of Henan Colleges (16IRTSTHN7) and Start-up Project for the High-level Researcher of North China University of Water Resources and Electric Power (400140837).

Conflicts of Interest: The authors declare no conflict of interest.

\section{Abbreviations}

The following abbreviations are used in this manuscript:

$\begin{array}{ll}\text { CHP } & \text { Combined Heat and Power } \\ \text { DH } & \text { District Heating } \\ \text { EC } & \text { Extraction Condensing } \\ \text { GH } & \text { Gland Heater } \\ \text { HBP } & \text { High Back-Pressure } \\ \text { HPT } & \text { High-Pressure Turbine } \\ \text { LPT } & \text { Low-Pressure Turbine } \\ \text { MPT } & \text { Medium-Pressure Turbine } \\ \text { RE } & \text { Relative Error } \\ \text { RH } & \text { Regenerative Heater } \\ \text { THA } & \text { Turbine Heat Acceptance } \\ \text { TMCR } & \text { Turbine Maximum Continuous Rating } \\ \text { TNH } & \text { Thermal Network Heater }\end{array}$

\section{References}

1. Sipilä, K. Cogeneration, biomass, waste to energy and industrial waste heat for district heating. Adv. Dist. Heat. Cool. (DHC) Syst. 2016, 45-73. [CrossRef]

2. Antonio, C.S.; David, B.D.; Enrique, R.A. District Heating and Cooling Networks in the European Union; Springer International Publishing: Berlin/Heidelberg, Germany, 2017.

3. Li, J.; Zhang, Y.; Tian, Y.; Cheng, W.; Yang, J.; Xu, D.; Wang, Y.; Xie, K.; Ku, A.Y. Reduction of carbon emissions from China's coal-fired power industry: Insights from the province-level data. J. Clean. Prod. 2020, 242, 118518. [CrossRef]

4. Chen, H.; Xiao, Y.; Xu, G.; Xu, J.; Yao, X.; Yang, Y. Energy-saving mechanism and parametric analysis of the high back-pressure heating process in a $300 \mathrm{MW}$ coal-fired combined heat and power unit. Appl. Therm. Eng. 2019, 149, 829-840. [CrossRef]

5. Ge, Z.; Zhang, F.; Sun, S.; He, J.; Du, X. Energy Analysis of cascade heating with high back-pressure large-scale steam turbine. Energies 2018, 11, 119. [CrossRef]

6. Lv, K.; Li, J.; An, J.; Wang, D.; Yu, X. Thermodynamic characteristics of a $330 \mathrm{MW}$ unit with high back-pressure circulating water heating. Turbine Technol. 2019, 61, 59-62+66. 
7. Li, P.; Nord, N.; Ertesvåg, I.S.; Ge, Z.; Yang, Z.; Yang, Y. Integrated multiscale simulation of combined heat and power based district heating system. Energy Convers. Manag. 2015, 106, 337-354. [CrossRef]

8. Li, Y.; Chang, S.; Fu, L.; Zhang, S. A technology review on recovering waste heat from the condensers of large turbine units in China. Renew. Sustain. Energy Rev. 2016, 58, 287-296. [CrossRef]

9. Li, W.; Zhao, J.; Fu, L.; Yuan, W.; Zheng, Z.; Li, Y. Energy efficiency analysis of condensed waste heat recovery ways in cogeneration plant. Energy Convers. Manag. 2015, 101, 616-625. [CrossRef]

10. Li, W.; Tian, X.; Li, Y.; Ma, Y.; Fu, L. Combined heating operation optimization of the novel cogeneration system with multi turbine units. Energy Convers. Manag. 2018, 171, 518-527. [CrossRef]

11. Zhao, S.; Ge, Z.; He, J.; Wang, C.; Yang, Y.; Li, P. A novel mechanism for exhaust steam waste heat recovery in combined heat and power unit. Appl. Energy 2017, 204, 596-606. [CrossRef]

12. Ma, L.; Ge, Z.; Zhang, F.; Wei, H. A novel super high back pressure cascade heating scheme with multiple large-scale turbine units. Energy 2020, 201, 117469. [CrossRef]

13. Chen, H.; Qi, Z.; Chen, Q.; Wu, Y.; Xu, G.; Yang, Y. Modified high back-pressure heating system integrated with raw coal pre-drying in combined heat and power unit. Energies 2018, 11, 2487. [CrossRef]

14. Ommen, T.; Markussen, W.B.; Elmegaard, B. Lowering district heating temperatures-Impact to system performance in current and future Danish energy scenarios. Energy 2016, 94, 273-291. [CrossRef]

15. Nesheim, S.J.; Ertesvåg, I.S. Efficiencies and indicators defined to promote combined heat and power. Energy Convers. Manag. 2007, 48, 1004-1015. [CrossRef]

16. Wang, H.; Jiao, W.; Lahdelma, R.; Pinghua, Z. Techno-economic analysis of a coal-fired CHP based combined heating system with gas-fired boilers for peak load compensation. Energy Policy 2011, 39, 7950-7962. [CrossRef]

17. Yannay, C.L.; Patricia, G.; Scarlett, C.; Claudio A, Z.; Luis E, A.P. Exergoeconomic valuation of a waste-based integrated combined cycle (WICC) for heat and power production. Energy 2016, 114, 239-252. [CrossRef]

18. Pouria, A.; Marc A., R.; Ibrahim, D. Greenhouse gas emission and exergo-environmental analyses of a trigeneration energy system. Int. J. Greenh. Gas Control 2011, 5, 1540-1549. [CrossRef]

19. Emin, A.; Haydar, A.; Arif, H. Advanced exergy analysis of a trigeneration system with a diesel-gas engine operating in a refrigerator plant building. Energy Build. 2014, 80, 268-275. [CrossRef]

20. Duccio, T.; Daniele, F. Thermo-economic assessment of a micro CHP system fuelled by geothermal and solar energy. Energy 2013, 58, 45-51. [CrossRef]

21. Yang, Y.; Li, P.; Ge, Z.; Tian, J.; Wang, N.; Song, Z. Green heating: Theory and practice. Sci. China Technol. Sci. 2015, 58, 2003-2015. [CrossRef]

22. Lund, H.; Ostergaard, P.A.; Chang, M.; Werner, S.; Svendsen, S.; Sorknaes, P.; Thorsen, J.E.; Hvelplund, F.; Mortensen, B.O.G.; Mathiesen, B.V.; et'al. The status of 4th generation district heating: Research and results. Energy 2018, 164, 147-159. [CrossRef]

23. Duan, J.; Zheng, W.; Wang, X.; Hao, Y. Technical and economic analysis of 150MW turbine unit about two reconstruction modes for high back pressure heating. Appl. Mech. Mater. 2013, 291-294, 1708-1713. [CrossRef]

24. Xue, Y.; Ge, Z.; Yang, L.; Du, X. Peak shaving performance of coal-fired power generating unit integrated with multi-effect distillation seawater desalination. Appl. Energy 2019, 250, 175-184. [CrossRef]

25. Cristina, S.S.; Marina, O.D.; Fontina, P. Exergy and economic evaluation of a hybrid power plant coupling coal with solar energy. Appl. Sci. 2019, 9, 850. [CrossRef]

26. STEAG. EBSILON®Professional Online Help: Steam Turbine/General Expander. Available online: https:/ /help.ebsilon.com/EN/webframe.html\#Component_6.html (accessed on 20 August 2020).

27. Steven, I.G.; Ramon, F.G.; Jose, C.C.; Denis, I.G. Critical review of the first-law efficiency in different power combined cycle architectures. Energy Convers. Manag. 2017, 148, 844-859. [CrossRef]

28. Wang, J.; Lu, Z.; Li, M.; Lior, N.; Li, W. Energy, exergy, exergoeconomic and environmental (4E) analysis of a distributed generation solar-assisted CCHP (combined cooling, heating and power) gas turbine system. Energy 2019, 175, 1246-1258. [CrossRef]

29. Stepanov, V.S. Chemical energies and exergies of fuels. Energy 1995, 20, 235-242. [CrossRef] 
30. Lund, H.; Werner, S.; Wiltshire, R.; Svendsen, S.; Thorsen, J.E.; Hvelplund, F.; Mathiesen, B.V. 4th Generation District Heating $(4 \mathrm{GDH})$ integrating smart thermal grids into future sustainable energy systems. Energy 2014, 68, 1-11. [CrossRef]

31. Li, J.; Gao, S.; Li, Y.; Lyu, J.; Gao, Z. Exergy Efficiency Analysis of Heating Steam Pipeline for Cogeneration Power Plant. Electr. Power 2018, 51, 53-58.

(C) 2019 by the authors. Licensee MDPI, Basel, Switzerland. This article is an open access article distributed under the terms and conditions of the Creative Commons Attribution (CC BY) license (http://creativecommons.org/licenses/by/4.0/). 